\title{
ABSTRACTS
}

\section{Renzi's Leadership between Party and Government} by Sergio Fabbrini and Marc Lazar

\begin{abstract}
This chapter discusses Renzi's leadership with regard to his party and the government. The main argument is that Renzi was able to use his party to support the government through his double role of secretary (of the party) and prime minister (of the government). However, the support of the party for the government's actions has been regularly contested by an internal left-wing faction and has been weakened by the disaggregation and political autonomy of the local and regional party organizations. The chapter describes and analyzes the divisions within the national party, the difficulty of controlling local and regional organizations and leaders, and the parliamentary achievements of the government, which came about due primarily to the popularity of the prime minister. The personal leadership of Renzi has been a resource for promoting governmental reforms, but a leadership unsupported by a party will have difficulty facing future political and policy challenges.
\end{abstract}

Keywords: Democratic Party, internal divisions, leadership, local power relations, regional elections, Renzi government

\section{The Center-Right's Search for a Leader: Crisis and Radicalization} by Francesco Raniolo

Abstract: This chapter deals with the political crisis of the Italian center-right that started with the fall of the Berlusconi IV government and the 2013 general elections. In 2015, the struggle for leadership of the center-right took place between Matteo Salvini and Silvio Berlusconi, resulting in the reversal of the balance of power between Forza Italia and the Lega Nord. Based on election results and some 
electoral surveys, Lega Nord seems to have become the third party at the national level and, through a process of radicalization, also the party of the new Italian right. From an organizational point of view, Salvini's leadership can be defined as a personalized and postmodern media leadership. The systemic risks of this scenario are the absence of a center-right party that can compete with the Partito Democratico led by Matteo Renzi, the growing fragmentation of the center-right, and the conflict between moderate and radical tendencies. All these factors challenge the return to an alternating democracy.

Keywords: bipolarism, center-right, fragmentation, leadership, media, polarization, radicalization

\title{
The May Regional Elections: Consolidation of the Tripolar System
} by Silvia Bolgherini and Selena Grimaldi

\begin{abstract}
The regional elections that were held in May 2015 have confirmed the changes that have recently been taking place in the politicalparty system in Italy: the end of the bipolar system and the emergence of a third pole consisting of the M5S. The tripolarism at the regional level can be attributed not only to the success of the M5S, but also to the loss of salience of the center-right and the disappointing performance of the center-left. In terms of the political offer, this election round showed an increase in party fragmentation and the average number of candidates and a greater variability in the number and type of coalitions than in previous contests. In terms of results, it showed a greater dispersion of the vote between the candidates for the presidency and identified the M5S and the LN as the two axes on which the new balance of power in the regions is centered.
\end{abstract}

Keywords: coalitions, election campaign, political offer, regional elections, regional party systems, tripolarism

\section{The Election of the President of the Republic in Unstable Times by Mark Donovan}

Abstract: Sergio Mattarella was elected the eleventh president of the Republic on 31 January 2015 for a seven-year term. His election after the fourth round of voting was a success for Matteo Renzi, the president of the Council of Ministers, who reunited his party, reinforced his government, and weakened his opponents. The new president was elected by 66 percent of the electoral college, a relatively large majority, comprising principally the left but also a small part of the moderate 
right. That majority might also be seen as a centrist establishment vote in a still polarized party and political system. This perspective suggests that in addition to the president's institutional significance, which may be sharply reduced in the near future due to major constitutional reforms, his importance as a national figure and socialization agent should also be considered. The president's ability to represent and enhance social cohesion may be particularly important in a more majoritarian political system.

Keywords: constitutional reform, national identity, president of the Republic, presidentialization, Sergio Mattarella, socialization agent

\title{
Italy's Foreign Policy Game: Moving without the Ball
} by Vittorio Emanuele Parsi

\begin{abstract}
In 2015, Italy's foreign policy was focused on issues that were linked to the attempt to boost Italy's international reputation: the Libyan question, the migration crisis, and Italy's role in the European Union. As for the first two issues, the Renzi government has sought to "Europeanize" them, with the aim of not being "left alone" in dealing with their consequences. The third issue concerns Renzi's effort to gain fiscal flexibility and "change the course" of the European Union. However, in Europe the prime minister has found himself isolated and has struggled to lead coalitions on issues that are very relevant for the national interest. The assessment of the Renzi government's action in foreign policy in 2015, ultimately, can be read in two ways: if it is evaluated against announcements, expectations, and demands of the prime minister, the result is disappointing; if it is measured in a more realistic fashion, the appraisal can be less harsh.
\end{abstract}

Keywords: budgetary flexibility, Europeanization, European Union, foreign policy, Libya, migration issue, national interest, refugee crisis

\section{School Reform: Innovation and the Rhetoric of Change}

by Gianluca Argentin and Carlo Barone

Abstract: In July 2015, the so-called Good School reform was approved. This measure introduces several novelties in the school sector, including an increase in resources. The reform was strongly promoted by Prime Minister Renzi, who has simplified the traditional processes of engagement with the teachers' unions. The aim is to empower school principals and teachers in a meritocratic framework, to overcome the lack of job stability for teachers by establishing new mechanisms of 
recruitment, and to open schools to extracurricular activities and vocational experiences. These important innovations, which are needed to improve the existing state of affairs, sound more like announcements rather than concrete commitments. In fact, there is a gap between the communication dimension of the reform, which is very effective, and its actual design, which in many aspects is approximate. There is therefore a real risk that the future implementation of the Good School reform might be less substantive than originally perceived.

Keywords: Good School reform, meritocratic model, plan for hiring teachers, school autonomy, school principals, trade unions

\title{
The Reform of the Public Administration: Centralization and Reorganization
}

by Fabrizio Di Mascio and Alessandro Natalini

\begin{abstract}
The modernization of the public administration has been one of the main objectives pursued by the Renzi government. What distinguishes the reform cycle launched in 2015 is the emphasis on centralization, unification, and the reduction of institutional fragmentation in the public sector after a long period in which autonomy and the organizational pluralism of administrations and government levels were enhanced. This reform strategy is consistent with the underlying trends of transformation in the political and institutional systems, in which the power of the prime minister has gradually increased. The actual impact of these reform measures, however, depends on concrete organizational instruments of subsequent implementing legislation in a context characterized by persistent spending cuts, which are necessary to maintain financial stability.
\end{abstract}

Keywords: administrative reform, austerity policies, centralization, fragmentation, public administration, public sector, unification

\section{A New Governance for Banks: The Short- and Long-Term Drivers of the Italian Financial Sector Reform}

by Manuela Moschella

\begin{abstract}
This chapter investigates the reforms of some important and distinctive sectors of the Italian financial system: the banche popolari and the fondazioni bancarie. These reforms are particularly relevant in the list of events that have marked the year 2015 because they are inextricably intertwined with revisions in the EU supervisory and regulatory architecture and because they are an integral part of the
\end{abstract}


broader government plan to revive economic growth after the fiscal crisis. In particular, the chapter analyzes the long- and short-term factors that set the stage for the reforms to take place. These include transformations in the large cooperative banks and the inaction of key parts of the domestic financial sector with regard to legislative and structural changes; competitive pressures deriving from the buildup of European financial integration; and the backing of domestic and international regulators such as the Bank of Italy, the IMF, and the EU Commission, among others.

Keywords: banche popolari, banking foundations, banking sector, financial sector reform, sovereign debt crisis

\section{Young Workers and the Labor Market Policies of Renzi's Government}

by Patrik Vesan

Abstract: This chapter analyzes some of the major labor reforms implemented by the Renzi government in 2015 in relation to youth employment, with reference to the Jobs Act. The strategy pursued by the executive has been to concentrate on combating the segmentation of the labor market by liberalizing individual and collective dismissals and by introducing a new type of contract, which offers a generous incentive for new permanent hires. The main goal of this strategy is to decrease the divisions between insiders and outsiders in the hope that this measure will encourage employers to stabilize workers, especially the younger ones, and invest in the development of human capital. Such a strategy, however, rests on weak foundations, which might call into question its effectiveness and with it the stability of Renzi's leadership.

Keywords: Jobs Act, labor market policies, segmentation of the labor market, Youth Guarantee, youth unemployment

\section{Expo 2015: An Opportunity to Relaunch Italy against the Back- ground of Local and Global Challenges}

by Renata Lizzi

Abstract: Expo 2015 represented a major challenge for Milan and Italy. Built around the theme "Feeding the Planet, Energy for Life," it combined local and global traditions, innovation, and technology, while establishing diplomatic and trade relations with many countries from around the world. The conclusion of a long process that had lasted about nine years, Expo 2015 was marked by difficulties in its 
governance and by delays in the implementation of its projects and works. After a brief review of this process, the chapter focuses on the events of 2015, the final race for the completion of works, and the event itself. It then discusses the theme that was chosen, including its representation by the various pavilions set up by the 158 participating countries. The final section discusses the outcome of Expo 2015 in terms of its legacy-the Milan Charter-and the economic opportunity for future development that the site presents.

Keywords: Expo 2015, food security, Milan Charter, nutrition, sustainable development, Universal Exposition

\title{
Migration and the Challenges of Italian Multiculturalism
}

by Christopher Hill, Sara Silvestri, and Elif Cetin

\begin{abstract}
The migration crisis is analyzed here in the context of the challenges that Italy faces as a country of immigration during a period of recession. It is argued that there has been no serious debate in Italy on multiculturalism or on religious freedom, despite the growing sociocultural and religious diversity arising from population movements and international conflict. The analysis begins with the Italian government's attempts in 2015 to deal with migration and diversity and the associated domestic conflicts at the levels of both party politics and civil society. The external dimension of Italian politics is examined in terms of Rome's impatient calls for EU help and the weak political position of Italy in relation to the root causes of migration. After discussing the meaning of the Christian/Catholic identity of the country in its present state, the chapter concludes that Rome has little choice but to develop a more long-term view with regard to diversity and integration.
\end{abstract}

Keywords: Catholicism, diversity, foreign policy, Islam, migration, multiculturalism, religion, security 